\title{
Social Entrepreneurship Marketing Communication Strategy in Maintaining Customer Loyalty
}

\author{
Dewi Rachmawati ${ }^{1}$, Taufan Teguh Akbari ${ }^{2}$, and Sandy Adithia ${ }^{3}$ \\ 1, 2 Fakultas Komunikasi, Institut Komunikasi dan Bisnis LSPR, Jakarta, Indonesia \\ ${ }^{3}$ Fakultas Bisnis, Institut Komunikasi dan Bisnis LSPR, Jakarta, Indonesia
}

\begin{abstract}
Social entrepreneurship is a part of the world of entrepreneurship which is a combination of conventional profit-oriented businesses with a movement that is oriented towards social change. Social entrepreneurship has the potential as a solution that creates innovation, solves social problems, as well as creates new, better social values. However, its new existence and its form which is a combination of the two opposing values is a big challenge for these business actors. One way that can be a bridge to answer this problem is through the right marketing communication strategy not only to find the right customers, but also to create loyalty in order to create a sustainable business ecosystem. Therefore, this study was conducted to examine the form of marketing communication strategies of social entrepreneurs in order to find the right form of strategy in maintaining customer loyalty. The approach taken is a descriptive qualitative methodology with in-depth interviews with several resource persons who are the founders or leaders of start-up Social Entrepreneurs. The results showed that the strategies implemented by start-up social entrepreneurs including DuAnyam, Wangsa Jelita $\&$ Sunkrisps were very diverse and mostly through digital channels. From this channel, they concocted various ways to keep customers loyal and get benefits from the social entrepreneur program.
\end{abstract}

Keywords: social entrepreneurship; marketing communication strategy; customer loyalty

\section{INTRODUCTION (12 PT, BOLD)}

Schumpeter, a leading economist said that the main foundation of entrepreneurship is to provide new innovations to society, especially when the modern capitalist system experiences problems and causes various problems in all spheres of people's lives such as the crisis experienced by the United States in 2008 and the European Union debt crisis in 2008. the early 2010s. (Sleidzik, 2013). Entrepreneurs are agents of change who solve the problems of social life, be it economic, cultural, or social problems. One of the challenges experienced by Indonesia is the existence of free competition globally which is increasingly competitive, especially in the AEC (ASEAN Economic Community). On the bright side, Indonesia's opportunities to develop are increasing but previous problems have been exacerbated by free competition such as high poverty and unemployment 
rates, widening social inequality, lack of health facilities, and low quality of education (Dwiyanto, 2018).

In its development, a new branch of entrepreneurship emerged, known as social entrepreneurship. The basic difference between social entrepreneurship and entrepreneurship is if entrepreneurship can carry out corporate social responsibility that is not in line with company values, in social entrepreneurship social responsibility, and company values go hand in hand (Alter, 2003).

Social entrepreneurship has the potential to effectively solve social problems in Indonesia. However, not all social entrepreneurship has such a business model. The customer's misunderstanding of the social mission of social entrepreneurship makes the resulting problem solving ineffective as well. Based on the latest data from the estimated results of the study by PLUS (2018), Indonesia has around 342,000 registered social entrepreneurs. The number is quite large in its development and this is because quite a lot of entrepreneurs are aware of the development of social entrepreneurship which can help answer social problems.

Social entrepreneurship or social-based entrepreneurship is a business model that maintains a balance of profits in business and positive social impacts on the environment in a sustainable manner, so as to be able to overcome social problems that exist in society. The role of social entrepreneurs can encourage the people's economy and distribute welfare through social missions, pioneering businesses, empowerment, social impact, professional business management, sustainability. Social entrepreneurs also think about the impact they have created in society. Therefore, social entrepreneurs can measure social impact using impact indicators that are monitored on an ongoing basis to see the level of alignment with the premise of change. This will help social entrepreneurs in measuring the size of the business and the reach and even the number of resources needed with a clear analysis (Nurdin, 2020).

Social entrepreneurship has also contributed to an increase in Gross Domestic Product (GDP) of 1.9 percent (PLUS, 2018). Although this contribution can be said to be minimal, the existence of the social entrepreneurship sector is able to provide creative and inclusive economic facilities. So that it can make it financially independent to support the process of economic development in Indonesia. In the future, it can be projected that the number of millennial social entrepreneurs in Indonesia will continue to increase and are based on brilliant ideas to alleviate social - and even environmental - problems, considering that the government is also very supportive of this sector by facilitating access to business permits (AKM Indonesia, 2019).

Therefore, an effective communication strategy is crucial. This study aims to examine the selected social entrepreneurs in carrying out existing communication strategies to find out whether the form of marketing communication strategies is effective in responding 
to the challenges of a social entrepreneur in finding a balance between profit and social impact. And what is the strategy of social entrepreneurs in retaining their customers. Also to examine the form of marketing communication strategies for social entrepreneurship actors in Indonesia, especially in finding a balance point between profits and the resulting social impact.

This research was conducted qualitatively on 3 selected business units that already have a sustainable social impact on the community, namely Duanyam, Wangsa Jelita and Sunskrisps. The magnitude of the social impact generated by social entrepreneurship is the main reference in research. This is intended to compare the marketing communication strategies carried out by social entrepreneurship in each stage and also to see customer loyalty.

The research questions are (1) Does the message content, structure, and delivery method of marketing strategy communications made by the three business actors affect the continuity between increasing social impact and profits generated? (2) To what extent is the customer's understanding of the marketing communication strategy made in influencing the level of loyalty? Knowing the marketing communication strategies carried out by business people studied in retaining customers at each stage.

Social entrepreneurship is a new spectrum in the world of entrepreneurship that can answer various problems. One of the big challenges that must be answered by social entrepreneurship in Indonesia is finding an effective marketing communication strategy to gain and maintain customer loyalty. The findings of this study are expected to provide an overview of the right form of marketing communication strategy for social entrepreneurship at various business levels.

This research is expected to be a guide for both researchers and social entrepreneurs in finding an effective and appropriate form of marketing communication strategy for their business. This research is also expected to enrich and develop scientific research in universities, and can enrich teaching and research materials, especially in Marketing Communication Science and Entrepreneurship in Indonesia.

\section{METHOD}

The approach taken in this research is to use a descriptive qualitative methodology. Descriptive research aims to provide a specific description of the situation, social arrangement or relationship; by using words or numbers (Neuman, 2013). While the paradigm used is the constructivist paradigm with in-depth interview techniques to several sources who are the founders or leaders of start-up Social Entrepreneurs, namely from Wangsa Jelita (Nadya Saib - Co Founder), Sunkrisps (co-founder couple Sandra Alfina and Ricky K. Chandra) and DuAnyam (Melya Winata as Co-Founder and Haga 
Ginting from the Business Development division). The selection of the speakers above is carried out purposively, focusing on the founders or highest leaders of start-ups that have been established for at least 3 years. In addition, there was also an in-depth discussion with an expert, namely Mr. Goris Mustaqim who is competent in the world of social entrepreneurship.

The pattern of data analysis applies a list of questions as the basic material for interviewing the research subjects. To strengthen the data obtained from the field, it is necessary to add secondary data through access to reference sources and other data. The results from the field can be translated into the process of interpreting and parsing data which will lead to differences, contradictions and similarities in situations, attitudes, and views on customer loyalty. In anticipating and avoiding errors in the analysis of primary data and secondary data, the validity of the data must be implemented after processing. The following stages are tested: (1). Collecting data gradually or continuously from research subjects, (2). Triangulation of data from various appropriate points of view, (3). Checking of research subjects. The theory and concepts used in this study use the theory of Digital Marketing Strategy by Dave Chaffey \& Fiona Ellis-Chadwick (2016). In addition, it also uses the SOSTAC model by PR Smith (2017) as a basis for in-depth interviews and matches social entrepreneurship communication strategies in maintaining customer loyalty. SOSTAC (Figure 1) focuses on the six most important elements of a business, namely situation analysis, objectives, strategy, tactics, action, and control.

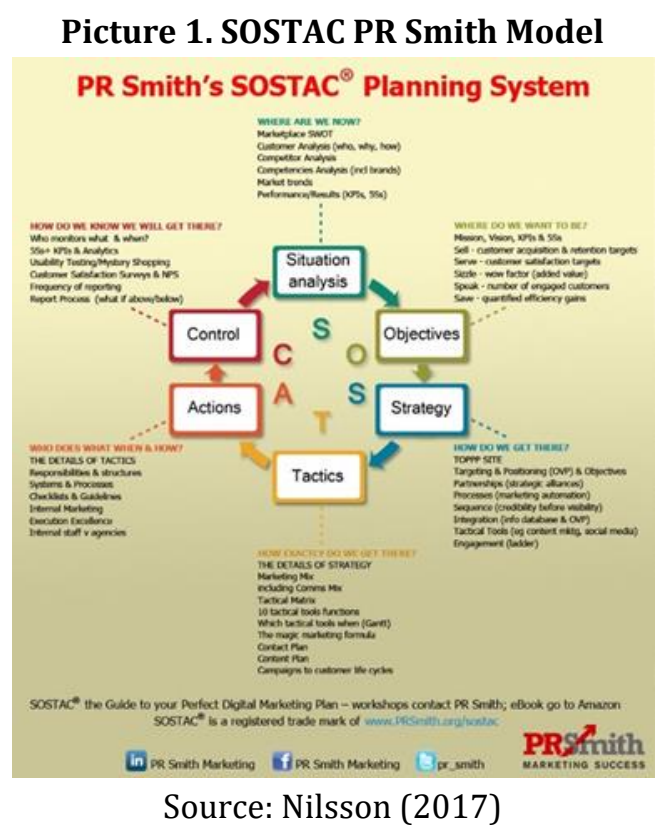

\section{RESULT AND DISCUSSION}

Social Entrepreneurs or social entrepreneurs who are the object of this research are Wangsa Jelita, Sunkrisps and DuAnyam. The first resource person to be interviewed was 
Nadya Saib as the Co-Founder of Wangsa Jelita. Wangsa Jelita is a social business that offers body care products with a natural concept, whose business implementation supports the empowerment of local communities. Wangsa Jelita is here because she sees the reality of beauty products on the market and also aims to educate the public about actual natural products (Wangsa Jelita, 2020). Wangsa Jelita was founded in 2008 when Nadya Saib graduated from bachelor degree majoring in Pharmacy - Bandung Institute of Technology. Together with two of her friends, Nadya Saib founded Wangsa Jelita because she saw the reality that many beauty products claim to be natural products, but after checking they are not really natural. Wangsa Jelita is here by presenting products that are truly natural. During its journey, Wangsa Jelita campaigned on Promoting Wellbeing, which is a healthy way of life and motivates young women, especially for a healthy lifestyle (Saib, primary data interview, 2020).

Picture 2. Wangsa Jelita Website Display

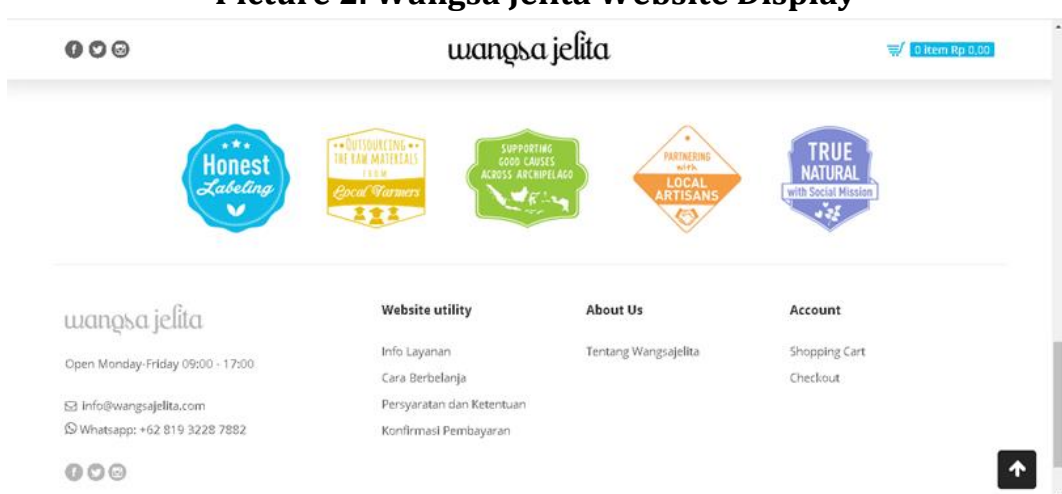

Source: Wangsa Jelita (n.d.)

The next social entrepreneur interviewed was Du Anyam. Du Anyam creates woven products through the most authentic craftsmanship with the aim of empowering the economy and improving the welfare of women in rural areas throughout Indonesia (Du Anyam, 2019). Du Anyam was founded in 2014, its focus is to empower women, improve welfare especially for mothers and to promote local culture through the production and distribution of handicrafts in remote areas in Indonesia. Since its establishment until now, more than 1200 mothers in 50 villages in 3 provinces have been empowered. The three provinces are East Nusa Tenggara, Papua, and South Kalimantan (Winata, primary data interview, 2020).

Picture 3. Du Anyam Website Display

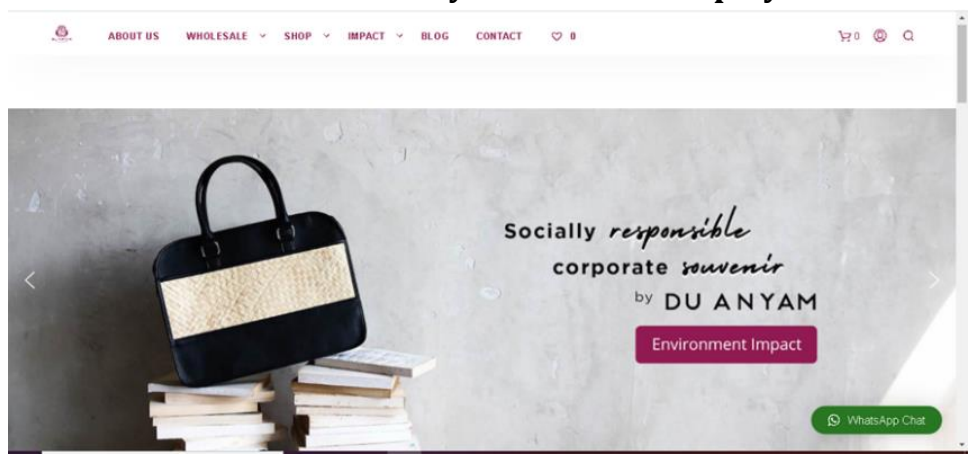

Source: Du Anyam (n.d.) 
Meanwhile, the last social entrepreneur interviewed in this study was Sunkrisps. Sunkrisps is a company that produces vegetable-based snacks, to help mothers in urban areas provide healthy eating companions for their families every day. Based in Indonesia, to be precise in Bogor, West Java. Sunkrisps empowers local vegetable farm products to be processed into healthy snacks and seasonings. Women's Empowerment is one of Sunkrisps' main concerns in the beneficiary/shareholder chain. 60\% Farmers, 87\% Employees, 90\% customers are all women who support Sunkrisps to develop until now. By supporting women, Sunkrisps has a more sustainable production chain that will lead to a sustainable business in the future (Sunkrisps, 2019).

Starting from 2015 where Sandra Alfina the founder who is really concerned about a healthy lifestyle, wants to make a healthy food product such as cookies, bread and almond milk. In 2017, the desire to spread a healthy lifestyle was also supported by Bekraf (Creative Economy Agency). Since then, the products have become diverse, one of which is vegetable chips. This enthusiasm to spread a healthy lifestyle from an early age is also accompanied by the empowerment of women who are the resources behind the success of Sunkrisps (Alfina, primary data interview, 2020).

\section{Picture 4. Sunkrisps Website Display}

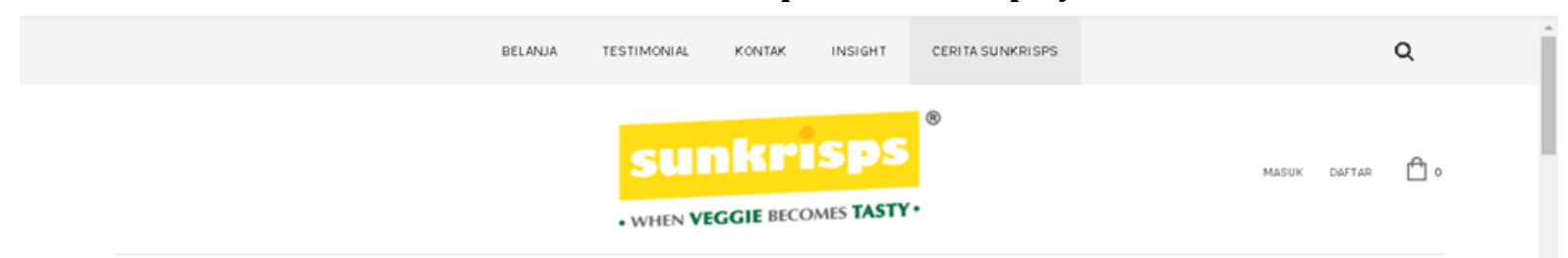

About SUNKRISPS

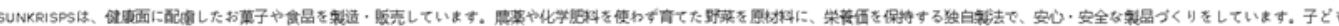

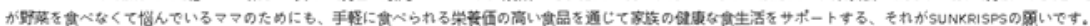

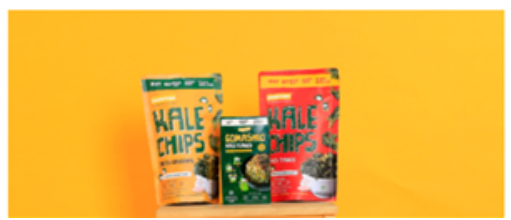

Source: sunkrisps (n.d.)

\section{Social Entrepreneurship Concept}

The concept of Social Entrepreneurship is currently considered quite successful and growing. Cunha \& Oliveira (2015) define social entrepreneurship as creating social value through innovation with a high degree of participant orientation, often with civil society participation and often with economic significance. Furthermore (Alvord et al. 2002) in Kummitha (2017) adds that various local initiatives around the world have significantly benefited from social entrepreneurship efforts. In recent times, however, various national governments have taken advantage of the innovative approaches adopted by 
social entrepreneurs to reduce social inequality and to overcome economic and employment barriers among disadvantaged groups. Experts believe that social entrepreneurship is not only meant to solve social problems, but to catalyze social transformation in an effective and efficient way.

Wangsa Jelita in its business process involves farmers as suppliers of ingredients for their products, such as rose and strawberry farmers in the Lembang-West Java area. For rose farmers in the area, the presence of Wangsa Jelita is an alternative solution in their marketing. Usually, the rose farmers sell their crops to middlemen who buy directly from the farmers' premises at a low price. The presence of Wangsa Jelita is an alternative for them, and of course in terms of price, they can also get a bigger profit. In addition, if their roses are rejected by the middlemen because their length or other criteria do not meet, the farmers now have another alternative to sell them to Wangsa Jelita. Not only farmers are involved in the business process, but also packaging crafters. Attractive packaging, especially for corporate gifts ordered to Wangsa Jelita, also makes craftsmen get orders in large quantities, especially at certain times such as Eid, Christmas or corporate events (Saib, primary data interview, 2020).

As a company engaged in the realm of social entrepreneurship, Du Anyam establishes its business as a hybrid company, where in addition to prioritizing profit value, Du Anyam also prioritizes social value, in the same weight. So when Du Anyam made a decision in business they always took both aspects into account. Whether in terms of profit and in terms of social value it has been fulfilled or not. Du Anyam raises local handicraft products, and always raises local wisdom from the area. For example, in NTT Du Anyam raised woven from palm leaves, which is a craft that is typical of the area. While in Papua, what is raised is using woven crafts from bark. From South Kalimantan itself, using woven crafts from purun plants. So, Du Anyam's mission is also to promote local culture. Starting from a village in East Nusa Tenggara with 8 mothers being fostered, Du Anyam tried to improve the skills of these mothers to what they are now. The woven craftswomen were also given training on how to improve quality, design training, and most importantly access to markets. And Du Anyam guarantees to access this market. So indeed, the business model is from upstream to downstream, from production, training, design, pricing, and market access, these are all done by Duanyam (Winata, primary data interview, 2020).

Starting from the desire of the founder who is concerned about healthy food, Sunkrisps was founded with the hope of being a solution for children who don't like vegetables. Present in the form of snacks that are rich in fiber, are expected to be an alternative to healthy snacks. This of course is also a solution for mothers, especially in urban areas who have difficulty dealing with children who do not want to consume vegetables. In its business process, Sunkrisps cooperates with farmers who are suppliers of raw materials for their products. Some of the farmers that Sunkrisps partnered with include some farmers in Bogor who supply vegetables, especially kale, carrot farmers in Berastagi and 
beetroot farmers who sometimes have to pick up from outside Java (Alfina, primary data interview, 2020). If you look at the Sunkrisps business process, where from upstream to downstream the social impact is very large, it is natural that it is included in the category of social entrepreneurship.

\section{Digital Marketing Strategy}

Digital marketing, previously referred to as e-marketing or internet marketing, is the core of digital business. Getting closer to customers and understanding them better will add value to their products, expand distribution channels and increase sales through digital marketing campaigns. Digital marketing referred to here is marketing using digital media channels such as search marketing, online advertising, affiliate marketing, the use of web sites to facilitate customer prospects, sales, and manage after-sales service (Chaffey \& Smith, 2017).

The commitment of Wangsa Jelita as a brand that wants to be closer to its end users began in 2014. At that time, Wangsa Jelita started using websites, Instagram and other social media. However, for content, it has only been really thought about since 2016. For the website itself, initially only as a display, but now it has grown even now its function is indeed an e-commerce. Wangsa Jelita also initiated a campaign with the title Promoting Wellbeing which was run apart from offline. In addition, the campaign was promoted through the Wangsa Jelita website and social media (Saib, primary data interview, 2020).

Du Anyam in running his business, initially mostly used offline strategy. The offline strategy that Du Anyam runs is such as direct meetings with clients, holding exhibitions and direct selling to prospective buyers by bringing product samples. Since $2019 \mathrm{Du}$ Anyam has begun to feel the need to beautify his appearance online which of course will support the offline strategy as well. Du Anyam's digital marketing strategy is through the website and social media. Since then, Du Anyam's website has been beautified and always updated. Likewise with social media, maintaining followers is an important thing to pay attention to. How to maintain positive interactions with followers, it is something that needs to be maintained and improved. Especially during the current Covid-19 pandemic, of course digital marketing is something that inevitably has to be adapted if you want the business to survive (Winata, primary data interview, 2020).

For Sunkrisps, resellers are the main force in its sales. Through resellers, more than $90 \%$ of whom are mothers, marketing is generally done through word of mouth both online and offline. The second power is through social media. Currently, social media has been widely used and is a tool that is quite helpful in marketing products. For websites, Sunkrisps also uses it but only for landing pages and creating awareness, because it is quite overwhelmed if sales are made through the website. In addition, Sunkrisps also sells through e-commerce, which is quite helpful in selling its products (Alfina, primary data interview 2020). 


\section{SOSTAC}

SOSTAC is a model in marketing communications, especially in marketing planning proposed by Paul Smith. SOSTAC stands for Situation analysis, Objectives, Strategy, Tactics, Action and Control. According to Nillson (2013) each element is a key step in the process. These six elements contribute to an important part of an organization's overall marketing plan. The understanding and application of the SOSTAC model in this study are as follows:

\section{Situation Analysis}

The situation analysis is divided into five, namely: Customer Analysis, Product Analysis, Competitor Analysis, Environmental Analysis covering social, economic, political, technological and environmental trends that affect business and SWOT Analysis (Strengths / Strengths, Weaknesses / Weaknesses, Opportunities / Opportunities, Threats / Threats) (Nillson (2013).

Wangsa Jelita was born from a desire to make products that are truly natural. This is because seeing the reality on the market there are many products that claim to be natural products, but when checked by the Wangsa Jelita Team, they are not really natural. The Wangsa Jelita team once made a survey that was distributed through social media about public opinion about the word natural in beauty products. From the survey, the results obtained are bipolar, where on the one hand there are people who simply believe in product claims as natural products without further checking about the composition. On the other hand, there are also extreme people who think that natural products are really products that are not mixed with chemicals. The results of the survey were used by the Wangsa Jelita team to formulate their natural products. In this case, what is done by Wangsa Jelita is an analysis of customers, products and competitors. For the SWOT analysis, Wangsa Jelita also does it to find out its market strength (Saib, primary data interview, 2020).

At the beginning of its establishment, Du Anyam conducted research related to the community's need for products such as woven boxes or commonly called besek, baskets and other packaging boxes. In addition, researching the use of these woven products. Some people use it to store household needs, store crops, there are even some places that use it for traditional ceremonies. Starting from the woven box, then the Du Anyam Team carried out market validation related to the needs of the community. Initially, the $\mathrm{Du}$ Anyam team sold to their closest people, friends, family, relatives and received feedback from the activity. One of the feedbacks is about the size that customers generally like. And it turns out that the size required by the market does not match the ones made by the craftsmen assisted by Du Anyam. Finally, an adjustment was made by the craftswomen and it was not easy for those who had been used to working for years like the previous measure (Winata, primary data interview, 2020). 
Melia Winata added that when it was first established, as a new brand, Du Anyam conducted competitor analysis. The purpose of doing a competitor analysis is to find out who the players in a similar business are. In addition, to find out the position of Du Anyam among these players. How is the segmentation of competitors, are they the same as Du Anyam or not? This is important to build the uniqueness of Du Anyam's business.

Regarding customer analysis, starting from a desire to popularize a healthy lifestyle and seeing the reality where many children don't like vegetables, Sunkrisps seized this opportunity and succeeded in becoming a social entrepreneur as it is today. For competitor analysis, Sunkrisps has also done this from the beginning and is still doing it until now. For now, according to Sandra, because Sunkrisps has also increased its level, Sunkrisps's competitors are not only local products. But also imported products that are also concerned with children by including vegetables in their products. However, there are also local products that are packaged like imported products so that the impression is that the food products are from abroad (Alfina, primary data interview, 2020).

\section{Objectives}

Objectives are a key element of the process strategy model. Companies need a basis of reference to help achieve the desired goals, such as the vision and mission of the company. Other things that play an important role in the objectives are as follows: (1). Sell - Sales to get customers and keep customers, (2). Serve - Service to get customer satisfaction, (3). Sizzle - WOW Factor as an additional value, (4). Speak - Communication in creating customer engagement and (5). Save - Measurable efficiency gains. (Nillson (2013)

Wangsa Jelita aims to introduce its products as completely natural products. On their website, Wangsa Jelita is committed to their products that are completely natural and free from additives such as surfactants, preservatives, moisturizers, fragrances, antibacterial, dyes, emulsifiers, solvents, mosquito and insect repellents, UV protectors, exfoliants (www. .wangsa jelly.com). In addition, Wangsa Jelita also helps provide solutions for people who have problems with sensitive skin by providing products that are safe but at affordable prices. As a brand that focuses on a healthy lifestyle, Wangsa Jelita has a big mission to campaign for Promoting Wellbeing, which is a mental health campaign. Armed with their networking with several experts in the field of mental health, well-being and emotional intelligence, Wangsa Jelita summarizes it all into positive things that they spread to their customers. In accordance with its vision and mission to provide products that are truly natural and also a solution for sensitive skin at a low price, Wagsa Jelita also

$\mathrm{Du}$ Anyam from its inception was indeed a social entrepreneurship that focused on empowering women, improving welfare, especially for women craftsmen and promoting local culture through the production and distribution of handicrafts in remote areas in Indonesia (Winata, primary data interview, 2020). 
As a social entrepreneur with a mission to live a healthy life, Sunkrisps provides healthy snack products that can be consumed by anyone, especially children who don't like vegetables. The targets are people who already have a healthy lifestyle or who are just starting to live a healthy life (Alfina, primary data interview, 2020).

\section{Strategy}

The strategy to be made must focus on the goals that have been made previously. In other words, strategy is about how to achieve goals. This method can be through targeting and positioning (targeting and positioning), partnership (partnership), process (process), sequence (sequence), integration (integration), tactictal tools (tactical tools), and engagement (involvement) (Nillson (2013) .

Like other Social Entrepreneurships, the strategy undertaken by Wangsa Jelita regarding customer retention is through partnerships with farmers and packaging crafters in their business processes. This is Wangsa Jelita's commitment to help farmers. In addition, the targeting and positioning that they do makes it easy to prepare the strategies they do. With the segmentation of young women and customers who have sensitive skin, Wangsa Jelita can place its brand in the hearts of its customers. Their Wellbeing Promoting campaign is a form of involvement (engagement) of Wangsa Jelita with its customers or customers.

The strategy taken by Du Anyam in retaining customers is, of course, by establishing good relationships with customers. Establishing a good relationship is usually realized starting from when approaching customers, during transactions and also after sales. For after sales, for example, after some time they were asked about consumer satisfaction with the products they bought. And also ask if there is any input you want to convey regarding the products purchased. This is done, of course, so that Du Anyam can continue to exist in running its business (Winata, primary data interview, 2020).

Sunkrisps in developing its marketing strategy always adapts to the times. Like during the Covid-19 pandemic, where many people began to realize the need to live healthy to maintain body immunity. Sunkrisps used this opportunity to boost a healthy lifestyle, one of which is by always consuming healthy foods, especially vegetables, which of course can increase the body's immunity. Product differentiation is also one of Sunkrisps' strategies to continue to exist and be consistent as a social entrepreneur who spreads the mission to live a healthy life. Currently, Sunkrisps is developing vegetable-based products that can be cooked quickly and in terms of nutrition, of course it is also higher than processed food (Alfina, primary data interview, 2020).

In marketing Sunkrisps products, the role of resellers is also very important. For this reason, resellers are also stakeholders who need to be maintained through good interaction and communication. Not infrequently Sunkrisps also asks resellers directly 
about feedback on the products they sell. This is done to get input, what needs to be completed, what is still lacking, which of course will affect the progress of the company. Sunkrisps also sometimes provides tips to resellers so that the products they sell sell quickly. Also given tips on maintaining good interaction and communication with customers. As a form of appreciation to resellers, Sunkrisps often provides gifts such as free shipping. And that makes resellers happy and excited because usually resellers give in large quantities in boxes. So that by giving free shipping, the reseller's profit will be bigger. In addition, since August 2020, Sunkrisps has implemented a point system for resellers. For resellers who can reach reseller star, they will be given an appreciation in the form of an Ipad Pro which will certainly be useful for resellers.

\section{Tactic}

Once the strategy has been developed as part of the marketing plan, the tactics must be implemented to achieve the company's strategy. Tactics can be referred to in the marketing mix, communications mix, and tactical mix (Nillson (2013).

To achieve the goals that have been set, Wangsa Jelita uses tactics in communicating, especially in terms of using social media. Wangsa Jelita created a social media communication guide that guides all teams in creating relevant content so that engagement with customers can be established. In creating content, Wangsa Jelita tries to provide benefits from the products or content they produce. In addition, Wangsa Jelita in its communication guide also applies polite but not too formal language. "How we position ourselves as a follower of the Jelita House, everything has rules," said Nadya Saib, Co-Founder of Wangsa Jelita.

Du Anyam's tactic in its after sales strategy is to establish good relationships with customers. Periodically, customers are sent news letters related to Du Anyam's activities and promotions. Occasionally, the business development team also contacted customers and asked how they were doing. In addition, he also asked after a long time whether there was any input to Du Anyam regarding the product he had purchased. Du Anyam puts his position as a person who is always there if needed by his customers (Ginting, primary data interview, 2020).

To carry out the strategy, it takes the right tactics and in accordance with the time. Like during the Covid-19 Pandemic, where of course many people did not expect this kind of impact. For this reason, monitoring of the situation and conditions, especially market conditions, must always be carried out. The second tactic that Sunkrisps follows is to always carry out product development research. Since March 2020, Sunkrisps has had its own Research \& Development team that develops healthy products. This team actively conducts research to produce new products that customers love. The third tactic is a wellinformed team with a good system, so the internal team must continue to improve themselves to be more advanced (Alfina, primary data interview, 2020). 


\section{Action}

Action is the last component in planning that describes the activities to be carried out, according to strategy and tactics. At this stage, the details of strategy and tactics are discussed. It is necessary to pay attention to who does what, assess whether it has human resources internally or whether it needs additional new staff with the necessary expertise or whether it requires assistance from an external agency or consultant. In addition, it must also see if it has the systems and processes needed, and work to regulate them (Nilson, 2013).

Wangsa Jelita in creating content invites people to think, even if they don't think, then at least smile or laugh. The point is to create a positive feeling or positive reaction from that person and spread it to those around him (Saib, primary data interview, 2020).

Du Anyam launched a new sub brand under Du Anyam called Krealogi by Du Anyam. Krealogi by Du Anyam is an MSME (Small and Medium Enterprises) ecosystem that was formed from $\mathrm{Du}$ Anyam's experience in fostering craftsmen in Indonesia for approximately 6 years. Guidance from upstream to downstream is carried out by $\mathrm{Du}$ Anyam for the craftsmen. Departing from the experience that there are still many MSMEs (Small and Medium Enterprises) that are not yet digital literate, Du Anyam has a desire to make these craftsmen open their knowledge regarding digital. In addition to digital, there is also guidance on how to control the quality of the products produced by craftsmen. Because there are still many products that are not standardized and the quality is not good so it is difficult to be accepted by the market. Even though the market for these handicrafts is quite large both locally and abroad. For MSMEs that are more advanced, they are also trained regarding planning, production, how to make the costing and supply chain (Winata, primary data interview, 2020).

In the future, Sunkrisps intends to provide more education to the public regarding healthy living by consuming vegetables. It is hoped that in the future the community can also visit or do factory visits, to be more aware of the vegetables they eat through their favorite snacks (Alfina, primary data interview, 2020).

\section{Control}

This stage aims to monitor customer views and opinions. The control phase is carried out by periodically evaluating whether what has been implemented has achieved the previously set goals. Furthermore, Nilson (2013) explains that progress monitoring can be done on a regular basis - daily, weekly, monthly or quarterly. It is important to ensure that at the end of the allotted time period, everything goes according to plan. This monitoring can be done using web analytics, KPIs, site visitor profiles, usability testing, customer satisfaction surveys, reporting frequency, and who reports to whom and what happens to that feedback as part of this monitoring process. (PR Smith in Nilson, 2013). 
Wangsa Jelita controls its customers through surveys that they distribute at least once a year. The survey is also complemented by in-depth interviews with customers regarding customer satisfaction, complaints and input (Saib, primary data interview, 2020).

In order to produce products that meet market needs, it is necessary to control the production process. Quality Control plays a very strict role in this matter, especially the products sold by Du Anyam are hand made products which are of course very difficult to standardize. Control of size, shape and resultant output is applied in this case. In addition, control at the time of delivery, where accuracy and packaging are things that are very guarded by Du Anyam so as not to disappoint customers. Control is also carried out by asking for testimonials from customers regarding the products and services provided by Du Anyam. Feedback given by customers for Du Anyam is a very important input in Du Anyam's business going forward (Winata, primary data interview, 2020).

Sunkrisps in maintaining the quality of its products follows ISO standards and certifications that apply to food products. In addition, laboratory tests are also carried out to ensure that nutritional standards are met and the food consumed is safe and healthy. Regular surveys every 6 months are also carried out by Sunkrisps to maintain its quality. The survey is not only for end users but also for resellers (Alfina, primary data interview, 2020).

\section{Customer loyalty}

Customer loyalty is often defined as brand loyalty, which is a condition in which customers have a positive attitude towards a brand, are committed to the brand, and intend to continue their purchases in the future (Mowen and Minor 1998) in Mardalis, A (2006). Kotler, Hayes and Bloom (2002) in Buchari Alma (2002) state that there are six reasons why an institution needs to gain customer loyalty. First: existing customers are more prospective, meaning that loyal customers will provide great benefits to the institution. Second: the cost of acquiring new customers is much greater than keeping and retaining existing customers. Third: customers who already trust the institution in one matter will also believe in other matters. Fourth: the operating costs of the institution will be efficient if it has many loyal customers. Fifth: institutions can reduce psychological and social costs because existing customers have had many positive experiences with institutions. Sixth: loyal customers will always defend the institution and even try to attract and advise others to become customers.

Since the beginning, Wangsa Jelita has positioned its brand as a brand that wants to be close to its customers. For this reason, Wangsa Jelita tries to understand its customers by conducting regular surveys and also by creating the concept of Wellbeing so that it can be accepted by its customers as a lifestyle. Not only is it easy to accept but actually makes people interested in learning more about the concept (Saib, primary data interview, 2020). 
According to Melia Winata, in an interview with the person concerned, to maintain customer loyalty, Du Anyam prioritizes 3 things, namely (1) Maintaining product quality. $\mathrm{Du}$ Anyam is very aware of the importance of the quality of the products produced by the craftsmen. For this reason, it is necessary to control the standards of the products produced. (2) Service, including maintaining punctuality and good handling at the time of delivery. Du Anyam tries to maintain the service they provide to be consistent. Not only service at the time of the first transaction, the second and even so the treatment must be the same. The service here includes punctuality at the time of delivery according to the client's wishes, good packaging handles at the time of delivery and helpful customer service. (3) Social Stories. The social story related to $\mathrm{Du}$ Anyam as a social entrepreneurship was deliberately not put at the beginning. Because Du Anyam wants customers to buy their products because they see the good quality of their products, good design, functional and desired by the market. Not because behind him there is a social entrepreneur background which is the empowerment of the craftsman community.

To maintain customer loyalty, Sandra Alfina \& Ricky Chandra as co-founders of Sunkrisps agreed that good quality is the main key. From the survey that Sunkrisps did, it was found that customers are satisfied and they can feel that Sunkrisps products are delicious and healthy. In addition, the price offered is also not so expensive but can have a greater impact on health. Another thing that needs to be maintained in maintaining customer loyalty is interaction. In interaction, the "Trust" aspect is very important so that customers can be loyal to Sunkrisps products. The language used also needs to be adjusted to the target market so that it is easily digested by customers. As a brand that is still growing, Sunkrisps maintains service, especially to the target market, especially mothers. Because mothers are usually the decision makers in household purchases, especially for their children. Usually at Sunkrisps, interactions with mothers are like friendly and close friends so they can engage.

\section{Review by Social Entrepreneurship Expert}

The social entrepreneurship expert interviewed in this study was Goris Mustaqim, a young man who was born in Garut and has a noble desire to advance his region. Goris Mustaqim founded the Asgar Muda Foundation in 2007 and was inaugurated in 2008 which is engaged in education, youth entrepreneurship, community development, microfinance and farmer empowerment. His motivation to build Garut was because he saw Garut's great potential but still underdevelopment (Rizky, 2014).

Goris also initiated the formation of the Putra Regional Development alliance which was established in 2017, currently consists of 132 people from all over Indonesia. The sons of this region have the same vision of developing the region so that it can be more equitable and more advanced in various activities. In addition, Goris Mustaqim is also a social entrepreneurship consultant at the Semut Nusantara Foundation. As a consultant, he provides assistance for community development, community-based entrepreneurship throughout Indonesia. 
Most of his clients are companies that carry out Corporate Social Responsibility (CSR) activities, then mentoring community-based entrepreneurs such as tourist villages, fishing cooperatives, and others. Goris provides assistance starting from institutional initiation, searching for local champions, mapping, business and market validation, as well as assistance for networking and in overcoming problems that arise in the social entrepreneurship business (Mustaqim, primary data interview, 2020).

According to Goris Mustaqim, social entrepreneurship is currently growing very rapidly. He predicts that in the future there will be a major shift in the direction of the social entrepreneurship sector towards digital. This has been seen since 2015 when traditional sectors have entered or adopted digital. Both from the agricultural, marine and other traditional business sectors. This is something that changes cannot be avoided in the future. Business mainstreaming is currently going digital and that's very helpful. Because the current market demand is more and more native and digital. For this reason, it needs to be balanced with digitalization so that it is not left behind and can capture the market. When the researchers asked about the digital marketing strategy currently being carried out by social entrepreneurship, Goris said that it is now sophisticated and cool. Then he said

"All the research that I used to do on marketing behavior for social entrepreneurship has all been used since I started using ambassadors or endorsers. Then many people do transparent pricing, how much \% is returned to benefeciaries, how much \% is for development contribution. Or using a selling vs impact strategy, for example, from how much was sold, what percentage was used for donations. Of what is purchased will be donated to others. And the digital momentum is because of digital marketing and spurring people to create creative content and create awareness and engagement."

If this statement is related to what was done by the Jelita House, Du Anyam and Sunskrisps, it is very relevant. Where the three social entrepreneurships inevitably have to go digital even though there are other marketing strategies that have been carried out. Because apart from being in the digital era, in addition to digital, there is also a market that can be embraced and advance its business. In addition, to increase awareness for people who are new to their business.

In maintaining customer loyalty, according to Goris, engagement with customers is very important. Both offline and online. How a business can survive will depend on how the business maintains good relations with its customers, including in the digital realm.

Regarding the current situation, according to Goris, the impact measurement of social entrepreneurship in Indonesia is still difficult to measure, and the situation is still rare and very early compared to other countries. Not all social entrepreneurship can measure the impact because it is still in the early stage and is still voluntary. And in Indonesia there 
is no obligation to report the impact. Research related to social entrepreneurship is still very little. There are not many studies related to the situation analysis of social entrepreneurship in Indonesia. Situation analysis in question can be in the form of social mapping and it is very diverse.

Furthermore, Goris also explained that this activity needed assistance for social entrepreneurship that was just developing both for programs and solutions. These solutions are related to community empowerment, stakeholder mapping, local champions so that they have an impact and have continuity for the community. Another activity is to carry out an assessment of the service, and recommend prerequisites for the sustainability of the program.

\section{CONCLUSION}

From the research conducted, it is found that each social entrepreneur has their own way of implementing their marketing strategies so that customers remain loyal. Some are done digitally, but some argue that human touch is also very important in retaining customers. The theory of Digital Marketing Strategy and SOSTAC that underlies this research can be applied with adjustments to each social entrepreneur. Recommendations from experts confirmed in this study, stated that social entrepreneurship has a great opportunity to develop in the future, not only during the pandemic but also after. However, clear regulations are needed from the government regarding social entrepreneurship. Further research on other aspects of communication related to social entrepreneurship is very interesting to study.

\section{REFERENCES}

Alter, K. (2003). Social Enterprise Tipology. Virtue Venture LLC.

AKM Indonesia. (2019, May 19). Potret Kewirausahaan Sosial di Indonesia. Akademi Kewirausahaan Masyarakat. https://akmindonesia.org/article/14/potretkewirausahaan-sosial-di-indonesia

Belch, G.E. \& Belch, M.A. (2004). Advertising and Promotion: An Integrated Marketing Communication Perspective. McGraw Hill-Irwin.

Buchari, A. (2002). Manajemen Pemasaran dan Pemasaran Jasa. Alfabeta.

Chaffey, D. \& Smith, P. R. (2017). Digital marketing excellence: planning, optimizing and integrating online marketing (5th ed.). Taylor \& Francis. 
Cunha, J., Benneworth, P., \& Oliveira, P. (2015). Social entrepreneurship and social innovation: A conceptual distinction. In L. C. Farinha, J. Ferreira, H. Smith, \& S. Bagchi-Sen (Eds.), Handbook of research on global competitive advantage through innovation and entrepreneurship (pp. 616-639). IGI Global.

Du'Anyam. (n.d.). About Us. Du Anyam. https://www.duanyam.com/pages/about-us/

Dwianto, A. S. (2018). Social Entrepreneurship: Inovasi Dan Tantangannya di Era Persaingan Bebas. Majalah Ilmiah Bijak, 15(1), 68-76. https://doi.org/10.31334/bijak.v15i1.133.g118

Kummitha, R. K. R. (2017). Social entrepreneurship and social inclusion. Springer Books.

Mardalis, A. (2006). Meraih Loyalitas Pelanggan. BENEFIT Jurnal Manajemen dan Bisnis, 9(2), 111-119. https://doi.org/10.23917/benefit.v9i2.1217

Neuman, W. L. (2013). Social Research Methods Qualitative and Quantitative Approach. Pearson.

Nilsson, D. (2013, April 30). SOSTAC® Marketing Model-Top Ranked Planning System. Medium. https://medium.com/@danielnilsson77/sostac-marketing-model-topranked-planning-system-66dabb931435

Nurdin, I. (2020, October 26). Ingin Menjadi Wirausaha Sosial yang Sukses? Ini Kuncinya! aceHTrend. https://www.acehtrend.com/2020/10/26/ingin-menjadiwirausaha-sosial-yang-sukses-ini-kuncinya/

PLUS. (2018). The State of Social Enterprise in Indonesia. British Council. https://www.britishcouncil.org/sites/default/files/the_state_of_social_enterpris e_in_indonesia_british_council_web_final_0.pdf

Rizky, J. (2014, February 4). Goris Mustaqim, Terpanggil Membangun Tanah Kelahiran. SWA Magazine. https://swa.co.id/swa/headline/goris-mustaqim-terpanggilmembangun-tanah-kelahiran

Śledzik, K. (2013). Schumpeter's view on innovation and entrepreneurship. S. Hittmar (Ed.), Management Trends in Theory and Practice (pp. 89-95). Faculty of Management Science and Informatics, University of Zilina \& Institute of Management by University of Zilina. https://dx.doi.org/10.2139/ssrn.2257783

Sunkrisps, (2019). Tentang Sunkrisps. Sunkrisps. https://www.sunkrisps.id/

Wangsa Jelita, (2020). Wangsa Jelita. Wangsa Jelita. https://www.wangsajelita.com/ 